discussions on the increased cost of living. It has also taken part in the consideration of problems involved in the reorganization of the Post Office through its Post Office Committee, and the Post Office Engineering and Stores Departmental Whitley Council. Preliminary consideration is also being given to the adequacy of the Carpenter scheme in view of the magnitude and rapidity of developments in scientific establishments since the publication of the Carpenter Report in 1930.

\section{The Strangeways Laboratory}

In the report for 1937 of the Strangeways Research Laboratory, Cambridge, the trustees are able to announce that an anonymous donor has guaranteed an additional $£ 500$ a year to the income of the trust for five years. This subscription has enabled the trustees to accept the offer of the Rockefeller Foundation of the capital cost of an extension. The new buildings will provide additional accommodation for laboratory work, and will enable satisfactory arrangements to be made for the library and the workshops. During the year, the record number of twenty-five persons has worked in the Laboratory, and it is a testimony to its reputation that of these, eleven should be visitors from other laboratories in Great Britain and abroad. The British Empire Cancer Campaign has equipped the Laboratory with a $200 \mathrm{kv}$. $\mathrm{X}$-ray apparatus, and has purchased a $300 \mathrm{mgm}$. radium plaque, which had been on loan. This has enabled the work on the irradiation of tissues to be continued, and it is now being extended from the preliminary observations in vitro, to the more difficult problems encountered in vivo. Of the sixteen papers published from the Laboratory during the year, nine are concerned with embryological problems, three with the effects of radiation on living material, and the remainder with the metabolism of tumour tissue and the physiology of the embryonic heart.

\section{Forest Products Research Board}

ThE report of the Forest Products Research Board for the year 1937 forms an introduction to the report of the Director of Forest Products Research at Princes Risborough for the same year (London: H.M. Stationery Office, 1938. 2s. net). The Research Board briefly reviews the work of the year and the measures laid down to be observed in future in the preparation of reports on mechanical tests of timbers ; the grading of structural timbers; and plywood and other materials built up from wood. An extensive investigation into the latter and allied materials is proposed; a study being made of 'composite wood', that is, of industrial materials made of laminated or disintegrated wood. An investigation is also to be carried out into the possibility of producing from home-grown timbers charcoal for use in the chemical and other industries, a prominent manufacturing firm having made an offer of a grant towards the cost of this work. The Director in his report acknowledges the important direct help which the physicist and chemist can give to the various branches of the timber-using industry.

\section{Central Medical School, Fiji}

THE Central Medical School at Suva, Fiji, founded in 1929, of which an account was given by Sir James Barrett in Nature of September 11, 1937, p. 472, has recently issued its annual report for 1937 . During the year, there were 43 students in the school, 13 of whom were in their first year, 13 in their second, 14 in their third and 3 in their fourth. In addition to students from Fiji, the school was attended by students from Samoa, Tonga, Cook Islands, Gilbert and Ellice Islands, Solomon Islands, New Hebrides and Nauru. The approximate annual cost for each student was $£ 74$, which included board and lodging, tuition fees, maintenance expenses, clothing, servants' wages, and pocket money, so that the four years' course of study amounted to about $£ 300$ per student. The average number of Fiji students who qualify each year is four, and there is an average annual loss of two. In Fiji, there is one native medical practitioner for every 1,600 of the population, and if the seven Indian medical practitioners and the 86,000 Indian population are included, there is one qualified man for 2,700 of population. Lists of the lecturers, prize winners and text-books used at the school are included in the report.

\section{Social Services and Venereal Disease}

THE Secretariat of the League of Nations has recently issued an account of the systems prevailing in different countries for the provision of social, as well as medical, services in the treatment of venereal disease ("Social Services and Venereal Disease". Geneva : League of Nations; London: Allen and Unwin. 1938. 1s. 3d.). The necessity for cheap medical treatment for venereal disease is now widely recognized, in some countries is com. pulsory, in others, including the United Kingdom, it is voluntary but is encouraged by the State. There is not the same wide recognition of the need for social help, and the number of countries where social service is combined with medical treatment at clinics and hospitals is still comparatively small. Where they exist, these social services take different forms. An account is given in the booklet of the systems in use in the United Kingdom and France, and suggestions are given for future planning which should prove of value to social workers in all countries.

\section{Yields of Fruit and Vegetables}

Some figures issued by the Ministry of Agriculture on September 2 outline the condition of various horticultural crops in many centres of Great Britain. Whilst the main interest of this survey is doubtless economic, it should also be interpreted as indicating a potent need for research into the cropping of fruit trees. Apple yields of Bramley's Seedling, Cox's Orange Pippin and cider varieties have only amounted to between 10 and 40 per cent of their capabilities. They were somewhat higher in 1937, but even then the crop average was decidedly below 50 per cent. Runner beans, Brussels sprouts, cabbage, carrots, parsnips, peas and onions yield, in general, crops of 60-80 per cent, and were slightly better last year. The poor cropping of the apple for 1937 and 1938 